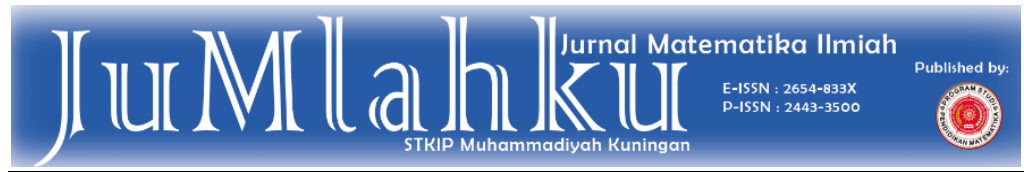

Submited: 2020-05-05

Published: 2020-06-12

\title{
Peranan Permainan Tradisional Engklek dalam Mengembangkan Kemampuan Matematika di Sekolah Dasar
}

Gita Anggrainia), Heni Pujiastutib)

a) (Program Studi pendidikan matematika, Fakultas keguruan IImu Pendidikan, Untirta) 2225170118@untirta.ac.id

b) (Program Studi pendidikan matematika, Fakultas keguruan IImu Pendidikan, Untirta) henipujiastuti@untirta.ac.id

\begin{tabular}{l}
\hline \multicolumn{1}{c}{ Article Info } \\
\hline Kaywords : Traditional \\
game of Engklek, \\
Mathematical skills, \\
Ethnomatematics
\end{tabular}

Abstract
The study aims to find out the role of mathematics in traditional
games of usually, the method used in this research is ethnography,
where researchers only do observations through documentation,
interviews and literature studies relating to traditional games of
marbles the type of research used is qualitative research. The subject
in this study was elementary school children in Umbul District Serang
Village. The results showed that there were mathematical elements
contained in traditional games of the crank. Traditional game of
usually teaches social values, such as honesty, patience,
cooperation, mutual respect, discipline, thoroughness can even
practice motor skills such as maintaining body balance, more active,
and use feeling in play, in addition the child begins to understand the
existence of mathematical associations in everyday life such as
mathematical elements of waking up flat, creating a straight line,
remembering the number of each box, the concept of opportunity.
With this children feel happy to learn mathematics by playing, and the
children also preserve the culture of Indonesia so as not to fade even
extinct is traditional game engklek.


Kata Kunci: Permainan tradisional engklek, kemampuan matematika, Etnomatematika
Penelitian ini bertujuan untuk mengetahui peranan matematika dalam permainan tradisional engklek, Metode yang digunakan dalam penelitian ini adalah etnografi, dimana peneliti hanya melakukan pengamatan melalui dokumentasi, wawancara dan studi literatur yang berkaitan dengan permainan tradisional kelereng jenis penelitian yang digunakan adalah penelitian kualitatif. Subjek dalam penelitian ini adalah anak-anak usia Sekolah Dasar di desa Umbul Kabupaten Serang. Hasil penelitian menunjukan bahwa adanya unsur matematika yang terkandung dalam permainan tradisional engklek. Permainan tradisional engklek mengajarkan nilai-nilai sosial, seperti kejujuran, kesabaran, kerjasama, saling menghargai, kedisiplin, ketelitian bahkan dapat melatih kemampuan motorik seperti menjaga keseimbangan tubuh, lebih aktif, dan menggunakan feeling dalam bermain, selain itu anak mulai memahami adanya kaitan matematika dalam kehidupan sehari-hari seperti unsur matematika bangun datar, membuat garis lurus, mengingat nomor setiap kotak, konsep peluang. Dengan ini anak-anak merasa senang belajar Matematika dengan bermain, dan anak turut serta melestarikan budaya Indonesia agar tidak luntur bahkan punah yaitu permainan tradisional engklek. 


\section{PENDAHULUAN}

Matematika merupakan mata pelajaran yang membutuhkan penalaran yang logis dan sistematis, karena matematika adalah ilmu dengan kajian konsep yang sifatnya abstrak (Amir, 2014). Pembelajaran penanaman konsep dasar sebagai jembatan dalam menumbuhkan perkembangan kemampuan berpikir peserta didik. Padahal matematika sangat diperlukan dalam mempelajari ilmu-ilmu lainnya (Wijayanti \& Trisiana, 2018). Matematika merupakan mata pelajaran yang sudah dipelajari sebelum masuk kedalam pendidikan formal. Seseorang sudah mulai mengenal angka maka pada saat itulah orang tersebut telah mempelajari matematika. Contohnya pendidikan formal pelajaran matematika ini telah dipelajari dari mulai TK, SD, SMP, SMA, sampai Perguruan Tinggi (Faridah, Jihan, Wahidin, 2019). Salah satu tujuan belajar matematika adalah membentuk skemata baru dalam struktur kognitif dengan mempertimbangkan skemata anak sehingga menjadi asimilasi Matematika merupakan pelajaran yang sering sekali di anggap sulit oleh siswa (Hartoyo, 2013). Kesulitan belajar di alami anak ada beberapa faktor yang menjadi penyebab siswa sulit memahami pembelajaran Matematika, Menurut (Ekawati \& Melda, Jaya, 2018)ada dua faktor yang mempengaruhi seorang anak mengalami kesulitan belajar yaitu faktor internal dan faktor eksternal. Siswa kurang termotivasi dalam pembelajaran matematika. Hal tersebut diduga karena pembelajaran yang dilakukan di dalam kelas masih bersifat konvensional dan kurang menarik bagi siswa. oleh karena itu siswa tidak memiliki dorongan dan semangat untuk belajar.

Guru memiliki peran sangat penting dalam proses membantu anak yang memiliki kesulitan belajar, namun masih banyak Guru menggunakan cara penyajian pelajaran matematika yang monoton, hal ini menyebabkan siswa sulit memahami matematika. Jika siswa sejak usia dini sudah tidak tertarik dengan pelajaran matematika, hal ini akan mengakibatkan siswa memiliki kemampuan matematis yang rendah, sedangkan Matematika di sekolah dasar mempelajari ilmu-ilmu berhitung yang mendasar sebagai bekal bagi siswa dalam memahami pendidikan pada jenjang selanjutnya. Untuk itu di sini terlihat bahwa peran guru sangat penting, guru diharapkan mampu 
menjadikan suasana pembelajaran yang menarik dan menyenangkan. Guru yang mampu menciptakan proses pembelajaran menjadi menyenangkan ini akan membuat siswa tidak lagi menganggap matematika sebagai pelajaran yang sulit dan membosankan, jika anak merasa senang dalam proses pembelajaran matematika, kemampuan matematika siswa menjadi baik.

Pendidikan dan budaya dalam konteks masyarakat tidak dapat dipisahkan antara satu dengan yang lainnya dengan demikian dapat dikatakan bahwa budaya merupakan perwujudan dari hasil pendidikan dan keduanya saling melengkapi (Dedi \& Elis, 2019). Indonesia dikenal memiliki kekayaan ragam budaya yang luhur. Budaya adalah harta kekayaan bangsa Indonesia yang sudah seharus dilestarikan keberadaannya. Nilai-nilai budaya lokal masih di budayakan oleh masyarakat, salah satunya ada pada permainan tradisional anak (Hendriana et al., 2019). Adanya kemajuan teknologi di era globalisasi ternyata telah menggeser kebiasaan anak-anak. baik dari kebiasaan perilaku dalam permainan, gaya hidup maupun cara belajar. Anak-anak sudah meninggalkan permainan tradisonal yang dianggap kuno dan tidak menyenangkan lagi, padahal banyak manfaat yang bisa didapat dari ragam permainan Tradisional (Febriyanti et al., 2018).

Permainan

modern

sebenarnya tidak sepenuhnya memberikan dampak negatif bagi para pemainnya, namun yang menjadi masalah adalah jika anak mulai kecanduan dengan permainan tersebut. banyak waktu yang terbuang sia-sia hanya demi menamatkan permainan(Maulida, 2019). Kemampuan anak usia SD di bidang matematika, tidak hanya diperoleh anak melalui pendidikan formal atau dalam atmosfer kelas, tetapi juga di lingkungan rumah, (Siregar \& Lestari, 2018). Melalui permainan yang tepat, guru akan membuat siswa bermain sekaligus belajar, sayangnya di era yang canggih ini jarang sekali di temukan siswa yang masih bermain bersama teman-temannya dengan permainan tradisional, siswa lebih suka bermain permainan di handphone, akibatnya siswa kurang bersosialisasi dengan teman dan lingkungannya. Permainan tradisional anak mengandung nilai budaya yang perlu dilestarikan. nilai budaya yang dibutuhkan bagi perkembangan dan 
pendidikan anak seperti nilai kebersamaan, saling tolongmenolong, serta kepemimpinan. Semakin jarangnya siswa bermain dengan permainan tradisonal yang ternyata melalui permainan ini mampu mengasah kemampuan kognitif dan motoric (Kusmiati \& Sumarno, 2018). Proses

kegiatan

pembelajaran dengan permainan tradisional ini tidak akan bersifat monoton yang hanya dilakukan di dalam kelas saja dengan berorientasi kepada hasil belajar, akan tetapi pembelajaran ini bertujuan untuk menciptakan proses penyajian pembelajaran yang diberikan oleh guru kepada siswa menjadi lebih menyenangkan dan tentunya lebih efisien. Interaksi yang terjadi pada saat anak melakukan permainan tradisonal memberikan kesempatan kepada anak untuk mengembangkan kemampuan sosial, melatih kemampuan bahasa, dan kemampuan emosi (Kurniati, 2011). Sebenarnya Anak-anak Indonesia harus mampu mempertahankan serta ikut serta melestarikan permainan tradisional ini. Permainan tradisional bukan sekedar permainan biasa, didalam permainan tradisonal mengandung unsur budaya yang kuat dan sudah seharusnya dilestarikan
(Yudiwinata \& Handoyo, 2014). Pendidikan dan budaya dalam konteks masyarakat tidak dapat dipisahkan antara satu dengan yang lainnya dengan demikian dapat dikatakan bahwa budaya merupakan perwujudan dari hasil pendidikan dan keduanya saling melengkapi (Nurjamil, Dedi, 2019). Perkembangan anak mengacu pada bertambahnya perubahan pengetahuan, perilaku, dan keterampilan yang semakin baik atau sesuai dengan tugas perkembangan pada usianya (Wulandari, Rifa \& Hurustyanti, 2016).

Bagian penting yang dapat di kembangkan pada anak yaitu kemampuan kognitif dengan melalui berbagai kegiatan dan permainan yang menyenangkan bagi anak. Kognitif merupakan suatu proses berpikir, yaitu kemampuan untuk menghubungkan, menilai, dan mempertimbangkan suatu kejadian atau peristiwa (Sugiarti \& Hasibuan, 2017). Sebenarnya banyak sekali unsur Pendidikan dan nilai-nilai sosial yang di dapatkan dari permainan tradisional, seperti kejujuran, kemampuan bekerjasama, kemampuan berinteraksi, menghargai teman serta dapat Keterampilanketerampilan gabungan perseptual 
motorik yang akan di dapatkan dalam permainan tradisional ini meliputi postur, keseimbangan (balancing), lokomotor, penerimaan, dan dorongan. Berdasarkan hal tersebut, kemampuan motorik merupakan komponen penting dalam individu untuk melatih gerakan dalam melakukan berbagai aktivitas seperti berlari, berjalan,melompat, mengguling, dan sebagainya. Permainan tradisional engklek merupakan permainan tradisional Sunda Manda sayangnya anak-anak di era sekarang jangang memainkan permainan ini. Peserta didik menyadari bahwa matematika itu penting, namun sebagian dari mereka sering mengalami kesulitan dalam mempelajari matematika, hal ini terjadi karena dalam proses pembelajaran guru tidak mengaitkan dalam kehidupan sehari-hari. Banyak sekali permainan tradisional yang bisa di gunakan dalam pembelajaran matematika, siswa akan lebih mudah memahami mata pelajaran matematika jika dikaitkan dengan kehidupan sehari-hari apalagi jika dijadikan permainan tradisional, yaitu permainan engklek (Ema, Butsi, 2013).

Permainan engklek merupakan permainan tradisional yang mengandung unsur pembelajaran matematika. Permainan engklek adalah permainan tradisional yang biasa dimainkan oleh anak-anak dengan cara melempar batu ke kotak lalu melompat dengan satu kaki dari satu kotak ke kotak lain ini merupakan pembelajaran matematika. Sehingga kita bisa menggunakan permainan tradisional engklek dalam pembelajaran matematika, dan siswa akan merasa senang mengikuti pembelajaran matematika. Secara tidak langsung, banyak manfaat yang di dapatkan dalam permainan tradisional engklek (Fitriyah \& Khaerunisa, 2018). Dari Hasil penelitian sebelumnya di simpulkan bahwa permainan tradisional berpengaruh secara signifikan terhadap kemampuan perseptual motorik anak (Kusmiati \& Sumarno, 2018), permainan tradisional engklek termasuk dalam permainan tradisional yang memiliki unsur matematika, hal ini sejalan dengan hasil penelitian sebelumnya yang menyatakan, pada permainan engklek anak membuat pola engklek dari berbagai bangun datar. Dalam membuat pola engklek bentuk pesawat, anak melukisnya dengan berbagai bangun datar seperti persegi, persegi panjang, dan trapesium. Membuat pola engklek 
bentuk orang, anak melukisnya dengan berbagai bangun datar seperti persegi, persegi panjang, dan lingkaran. Engklek bentuk

lemari, anak membuat polanya dari rangkaian persegi panjang (Siregar \& Lestari, 2018) Oleh karena itu peneliti ingin melakukan penelitian ini, bertujuan untuk mengetahui apakah anak mengetahui bahwa adanya matematika dalam permainan tradisonal engklek dan diharapkan melalui proses pembelajaran permaianan tradisional engklek ini dapat menarik minat siswa terhadap matematika, sekaligus melestarikan kebudayaan Indonesia serta mengajarkan sikap social, seperti kejujuran, kerjasama, dan sabar, serta dapat melatih kemampuan motoric siswa.

\section{Metode}

Metode yang digunakan dalam penelitian ini adalah etnografi, dimana peneliti hanya melakukan pengamatan melalui dokumentasi, wawancara dan studi literatur yang berkaitan dengan permainan tradisional engklek. Jenis penelitian ini adalah kualitatif yang hanya mendeskripsikan bagaimana cara permainan dan manfaat yang diperoleh dalam permainan engklek tersebut serta hubungan permainan tradisional engklek tersebut dengan matematika.

Penelitian ini dilaksanakan di Desa Umbul, Kecamatan Petir, Kabupaten Serang Subjek penelitian adalah anak-anak usia Sekolah Dasar sebanyak 6 orang.

Teknik pengumpulan data dilakukan dengan langkah-langkah sebagai berikut: tahap pralapangan merupakan kegiatan pemilihan lokasi lapangan sesuai dengan kebutuhan, memilih responden, menyiapkan perlengkapan penelitian berupa sebatang kayu untuk membuat kerangka engklek meja di tanah. Selanjutnya tahap kegiatan lapangan merupakan kegiatan penelitian dengan melakukan penelitian dan melakukan wawancara kepada responden, dan adanya dokumentasi pada saat penelitian.

\section{Hasil dan Pembahasan}

Permainan tradisional di jaman modern ini sudah jarang di mainkan oleh anak-anak, mereka lebih suka bermain dengan digital dan internet, bahkan permainan tradisional kini sudah mulai luntur termasuk permainan tradisional engklek. Banyak yang tidak menyadari bahwa banyak sekali manfaat yang ada di dalam permainan tradisional termasuk adanya peran matematika yang ada di 
permainan tradisional. Di dalam permainan tradisional mengajarkan nilai-nilai sosial, seperti kejujuran, kesabaran, kerjasama, saling menghargai bahkan dapat melatih kemampuan motorik anak. Anak di era globalisasi ini cenderung sulit bersosialisasi dengan teman sebaya, karena mereka lebih suka bermain permaina dengan handphone secara individu, maka jangan heran jika banyak di temui anak yang menutup dirinya, bersikap diam dan tidalk mau bertemu dengan lingkungan sekitarnya. Permainan tradisional engklek pertama kali masuk di Indonesia pada masa penjajahan Belanda, permainan ini di beri nama Zondag Maandag, dan sekarang banyak yang mengenalnya dengan nama permainan engklek.

Peneliti memilih tempat penelitian di Desa Umbul, Kecamatan Serang, Kabupaten Serang karena di desa ini masih banyak sekali di temukan anak-anak perempuan yang bermain engklek dengan temantemannya. Permainan engklek ini bisa di lakukan di mana saja bisa di lapnagan, halaman rumah. Dengan alat yang di gunakan untuk menggambar kerangka permainan engklek ini dengan kayu ataupun kapur. Banyak sekali bentuk kerangka yang sering di gunakan dalam permainan engklek, saat penelitian anak-anak menggambar kerangka dengan sebutan engklek meja.

Sebelum permainan di mulai salah satu anak menggambar kerangka engklek meja dengan kayu, karena saat penelitian mereka bermain di lapangan yang masih ber alas tanah Dengan menggunakan kayu yang di gambar di tanah salah satu anak menggambar kerangka.

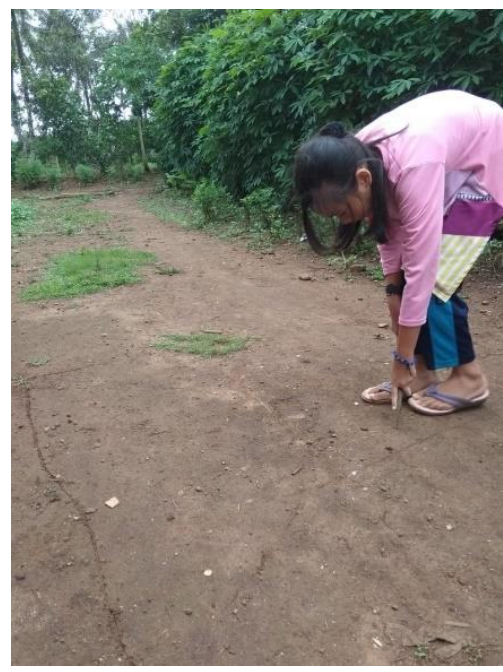

Gambar 1. Membuat Gambar Engklek Meja, dengan membuat garis yang luirus.

Membuat kerangka engklek meja, dengan membuat garis sehingga berbentuk persegi, persegi 
panjang dan trapesium, saat menggambar anak tidak menggunakan penggaris atau alat khusus lain untuk membuat garis agar lurus dan sama panjang, dari hasil wawancara peneliti, untuk menggambar kerangka dengan lurs dan sama besar, anak hanya menggunakan feeling dan perkiraan saja, jika tidak lurus mereka menghampus Kembali garis dan meluruskannya, mereka menyebut kerangka engklek ini dengan sebutan engklek meja karena gambar yang di bentuk seperti bentuk meja

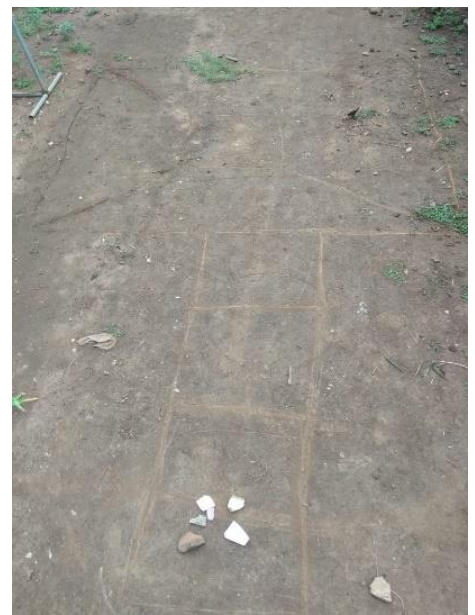

Gambar 2. Kerangka engklek meja.

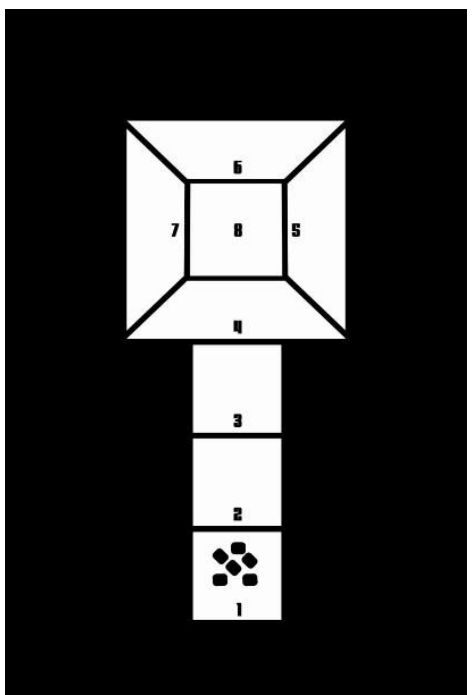

Gambar 3. Kerangka engklek meja.

Dari hasil wawancara peneliti di dapatkan bahwa mereka tidak menyadari bahwa ada unsur matematika di dalam permainan engklek meja tersebut, mereka hanya mengenal satu bangun datar saja seperti persegi , Ketika peneliti bertanya bentuk apa lagi yang ada di kerangka engklek meja ini, salah satu anak menjawab bahwa bentuk lainnya adalah atap rumah, dari hasil wawancara ini di dapatkan bahwa anak-anak di desa umbul ini belum menyadari adanya pembelajaran matematika di dalam permaianan engklek meja. Pada saat penelitian jumlah anak dalam permainan engklek terdiri dari 6 orang dan aturan 
bermain engklek setiap anak harus memiliki satu batu, sehingga ada 6 batu yang di letakkan di kotak pertama yang berbentuk persegi.

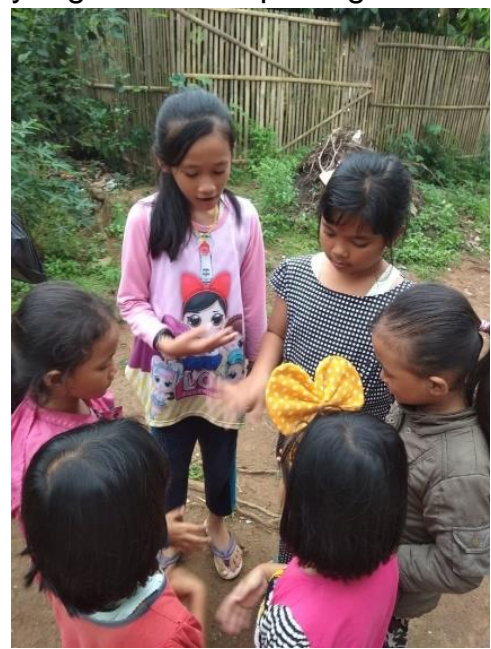

Gambar 4. Melakukan hompimpa untuk menentukan urutan bermain.

Aturan dalam permainan engklek ini sederhana, setelah menggambar kerangka engklek meja, mereka melakukan hompimpa untuk menentukan urutan siapa duluan yang akan bermain. Dengan di lakukan hompimpa akan di dapatkan urutan pertama sampai dengan urutan terakhir, hompimpa ini akan menghasilkan urutan yang adil karena sudah di setujui oleh anak-anak yang menjadi perserta dalam permainan engklek meja. Setelah di tentukan urutan pertama sampai urutan terakhir, anak yang mendapatkan urutan pertama di persilahkan untuk bermain terlebih dahulu,

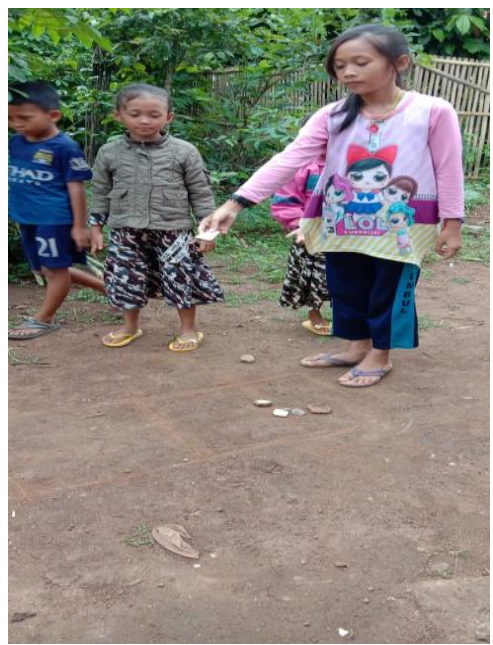

Gambar 5. Melempar batu ke dalam kotak

Anak yang mendapatkan urutan pertama memulai permainan dengan cara melempar bat uke melompat dengan satu kaki ke kotak yang tidak ada batu dan ke kotak urutan lainnya, di dalam kerangka engklek meja ada 8 kotak, semua kotak di lalui dengan satu kaki hanya di kotak no 8 atau yang ada di tengah kerangka anak menggunakan dua kaki. 


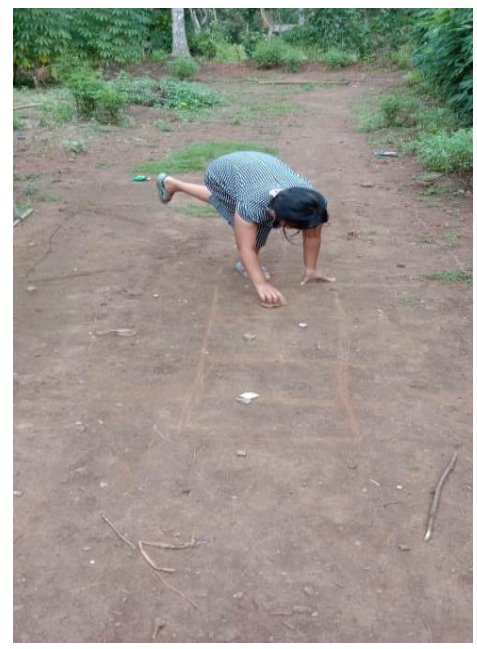

Gambar 6.mengambil batu sebelum kembali ke kotak awal dan finish.

Anak kembali lagi dengan satu kaki sebelum ke garis finish, anak mengambil terlebih dahulu batu dan di bawa sampai garis finish, batu yang di genggam anak tidak boleh terjatuh sampai kembali lagi ke kotak pertama, anak melemparkan batu ke dalam kotak selanjutnya dan tidak boleh keluar dari garis kotak, dalam melempar batu ini anak harus mampu menyeimbangkan tubuhnya dan membuat perkiraan agar batu yang di lempar tepat berada di dalam kotak selanjutnya. Jika dalam permainan anak menginjak garis itu berarti anak sudah kalah, dan bergantian dengan urutan selanjutnya. Semua anak mempunyai kesempatan yang sama dalam bermain, permainan terus berjalan hingga sampai ada anak yang sudah bisa menempatkan batu ke dalam kotak no 8 , jika sudah di tahap ini anak mengambil batu dengan menghadap ke depan dalam arti anak mengambil batu tanpa melihat ke belakang dan tidak boleh menyentuh garis.

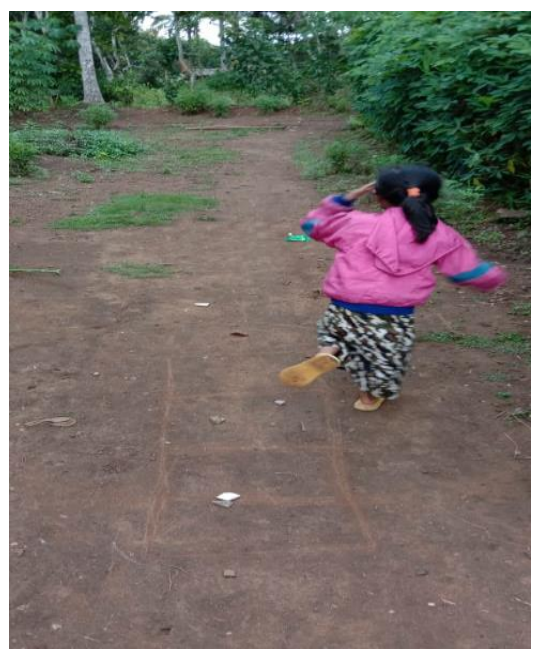

Gambar 6. Anak menggunakan kotak telinga untuk mempermudah menginjak kotak selanjutnya

Permainan semakin sulit, karena anak tidak boleh menginjak kotak yang sudah ada batunya, maka dari itu anak harus mempunyai keseimbangan tubuh yang baik. Jika kotak yang tidak ada batu terlalu jauh untuk di injak, anak-anak bekerja 
sama membuat kotak bantuan yang berbentuk setengah lingkaran $\mathrm{di}$ sebelah kanan kotak, mereka memberi sebutan kotak telinga. Permainan di anggap selesai jika sudah ada anak yang selesai menaruh batunya ke dalam kotak 8 atau anak menyebutnya dengan sebutan kotak meja, dan anak yang mampu menyelesaikan permainan di anggap sebagai pemenang.

Jika kita lihat dari hasi penelitian ini banyak sekali manfaat dari permainan tradisional engklek, dengan adanya permainan tradisional engklek membantu perkembangan kognitif anak, mengenal bangun datar, membuat garis lurus, mengingat nomor setiap kotak, konsep peluang. Nilai yang di dapatkan di dalam permainan tradisional engklek ini adalah anak belajar kejujuran, kedisiplinan, Kerjasama, ketelitian, dan menghargai orang lain, selain itu dengan permainan engklek anak belajar keseimbangan tubuh, lebih aktif, dan menggunakan feeling dalam bermain hal ini sejalan dengan hasil penelitian (Rusja et al., 2017). Pembelajaran matematika sangat perlu memberikan muatan/menjembatani antara matematika dalam dunia sehari-hari yang berbasis budaya lokal dengan matematika sekolah. Dengan ini anak ikut serta dalam melestarikan budaya Indonesia yang mulai luntur. Anak juga semakin tertanam nillai kejujuran, Kerjasama, tolong menolong, saling menghargai serta di siplin, hal ini sama seperti penelitian yang telah di lakukan oleh (Yudiwinata \& Handoyo, 2014) Permainan tradisional yang melatih ketangkasan dan keseimbangan fisik dan dilakukan secara berkelompok, permainan ini melatih kerjasama dan ketelitian anakanak, dalam permainan ini kerjasama akan mampu membentuk anak-anak jauh lebih aktif dalam kehidupan sosialnya di waktu mendatang.

\section{PENUTUP}

\section{Simpulan}

Melalui penelitian mengenai Peranan permainan tradisional engklek dalam mengembangkan kemampuan matematika di sekolah dasar, di dapatkan bahwa permainan engklek ini di dapatkan unsur matematika seperti bangun datar, namun anak belum menyadari adanya unsur matematika di dalam permainan engklek ini, karena mereka hanya bermain sesuai aturan yang sudah ada, mereka baru mengetahui ternyata banyak unsur matematika 
yang mereka temukan di dalam kehidupan sehari-hari, pada proses permainan terlihat sekali bahwa anak memiliki sifat sosial yang baik seperti kerja sama, kejujuran, saling menghargai dan kesabaran. Selain itun anak juga terlihat aktif dan lincah dalam proses mengikuti permainan engklek dan dari hasil wawancara mereka juga mengatakan bahwa ada banyak sekali macam-macam bentuk kerangka permainan engklek ini, dan semua gambar memang ada di pembelajaran matematika yang guru mereka ajarkan di sekolah, dan mereka senang karena ternyata mereka bisa mengenal matematika dengan bermain.

\section{Saran}

Permainan tradisional engklek merupakan budaya Indonesia yang sudah seharusnya kita lestarikan, dan banyak sekali manfaat yang di dapatkan anak dalam permainan engklek, salah satunya adalah anak merasa senang mengenal matematika dengan bermain. Melalui penelitian ini diharapkan Guru di Sekolah Dasar memanfaatkan permainan engklek ini sebagai media pembelajaran matematika di sekolah, bertujuan agar anak bisa memahami materi matematika dengan baik, dan anak juga bisa mengenal dan melestarikan budaya Indonesia. Dan di harapkan untuk peneliti selanjutnya bisa meneliti lebih lanjut tentang peranan permainan tradisonal terhadap matematika khususnya permainan engklek.

\section{DAFTAR PUSTAKA}

Amir, A. (2014). Pembelajaran Matematika SD dengan Menggunakan Media Manipulatif. Forum Paedagogik, VI(1), 72-89.

Dedi, N., \& Elis, N. (2019). Eksplorasi Unsur Matematika Dalam Pembuatan Batik Khas Tasikmalaya. Jurnal Matematika IImiah STKIP Muhammadiyah Kuningan, 5(2), 111-119.

Ekawati, \& Melda, Jaya, S. (2018). Kesulitan Belajar Matematika Berkaitan dengan Konsep pada Topik Aljabar : Studi Kasus pada Siswa Kelas VII Sekolah ABC Lampung. $A$ Journal of Language, Literature< Culture, and Edicationournal of Language, Literature Culture, and Edication, 14(1), 53-64.

Ema, Butsi, P. (2013). Pemanfaatan Etnomatematik Melalui Permainan Engklek Sebagai Sumber Belajar. Journal of Separation Science and Engineering, 5(1), 11-21. http://scholar.google.com/schola 
$r ? h l=e n \& b t n G=S e a r c h \& q=i n t i t l e:$ $\mathrm{No}+\mathrm{Title \# 0}$

Faridah, Jihan, Wahidin, H. B. (2019).

Penerapan Metode Problem

Solving Berbantu Benda Konkret Untuk Meningkatkan

Kemampuan Berpikir Kreatif Matematis Siswa. JUMLAHKU, 5(2), 25-38.

Febriyanti, C., Prasetya, R., \& Irawan, A. (2018). Etnomatematika Pada Permainan Tradisional Engklek Dan Gasing Khas Kebudayaan Sunda. Barekeng: Jurnal IImu Matematika Dan Terapan, 12(1), 1.

https://doi.org/10.30598/vol12iss 1pp1-6ar358

Fitriyah, A., \& Khaerunisa, I. (2018). Pengaruh Penggunaan Metode Drill Berbantuan Permainan Engklek Termodifikasi terhadap Kemampuan Pemecahan Masalah Siswa Kelas VII. Journal of Medives: Journal of Mathematics Education IKIP Veteran Semarang, 2(2), 267. https://doi.org/10.31331/medive s.v2i2.653

Hartoyo, A. (2013). Etnomatematika Pada Budaya Masyarakat Dayak Perbatasan Indonesia-Malaysia. Jurnal Pendidikan Matematika Dan IPA, 2(1). https://doi.org/10.26418/jpmipa. v2i1.2180

Hendriana, B., Wahyuningsih, \& Supriadi, E. (2019). Pengaruh penggunaan media pembelajaran cangkang kerang terhadap motivasi belajar siswa sekolah dasar di Kab. Sikka. Jurnal Matematika IImiah STKIP Muhammadiah Kuningan, 5(2), 1-11.

Kurniati, E. (2011). Program Bimbingan Untuk Mengembangkan. 1-18. http://file.upi.edu/Direktori/FIP/J UR._PGTK/197706112001122EUIS_KURNIATI/pedagogia.pdf Kusmiati, A. M., \& Sumarno, G. (2018). Pengaruh Permainan Tradisional terhadap Kemampuan Perseptual Motorik Anak di SDN Margawatu II Garut Kota. TEGAR: Journal of Teaching Physical Education in Elementary School, 1(2), 17. https://doi.org/10.17509/tegar.v1 i2.11934

Maulida, S. H. (2019). Pembelajaran Matematika Berbasis Etnomatematika Melalui Permainan Tradisional Engklek. 561-569.

Nurjamil, Dedi, D. (2019). Eksplorasi Unsur Matematika Dalam Pembuatan Batik Khas Tasikmalaya. JUMLAHKU, 5.2(8), 111-119. https://doi.org/10.15036/arerugi. 44.8212

Rusja, J., Rosyid, A., \& Umbara, U. (2017). Penerapan Model Pembelajaran Contextual Teaching And Learning (Ctl) Berbasis Ethno Mathematics 
Terhadap Kemampuan Berpikir Kreatif Matematik Siswa. Jurnal Matematika IImiah STKIP Muhammadiah Kuningan, 3(2), 57-62.

Siregar, N., \& Lestari, W. (2018). Peranan permainan tradisional dalam mengembangkan kemampuan matematika anak usia sekolah dasar. Jurnal Mercumatika: Jurnal Penelitian Matematika Dan Pendidikan Matematika, 2(2), 1. https://doi.org/10.26486/jm.v2i1. 427

Sugiarti, A. N. D., \& Hasibuan, R. (2017). Pengaruh Permainan Engklek Modifikasi Terhadap Kemampuan Kognitif Mengenal Lambang Bilangan Kelompok A TK Tunas Harapan Plandaan Jombang. PAUD Teratai, 6(3).

Wijayanti, R., \& Trisiana, A. (2018). Pengaruh Permainan Engklek Berbasis Berpikir Kritis Peserta Didik Kelas lii. Jurnal Sinektik, 1. Wulandari, Rifa, S., \& Hurustyanti, H. (2016). Character Building Anak Usia Dini Melalui. Journal Indonesian Language Education and Literature, 2(1), 22-31.

Yudiwinata, H. P., \& Handoyo, P. (2014). Permainan Tradisional dalam Budaya dan Perkembangan Anak.

Paradigma, 2, 1-5. 